\title{
Analisis Minimalisasi Biaya Penggunaan Psikotropika pada Pasien Remaja dengan Disabilitas Intelektual di Rumah Sakit Jiwa Provinsi Jawa Barat Tahun 2015-2017
}

\author{
Ice L. Nur ${ }^{1}$, Neily Zakiyah ${ }^{2}$, Auliya A. Suwantika ${ }^{2}$ \\ ${ }^{1}$ Program Studi Magister Farmasi Klinik, Universitas Padjadjaran, Sumedang, Indonesia \\ ${ }^{2}$ Departemen Farmakologi dan Farmasi Klinik, Fakultas Farmasi, Universitas Padjadjaran, \\ Sumedang, Indonesia
}

\begin{abstract}
Abstrak
Obat-obatan psikotropika merupakan obat-obatan yang paling banyak digunakan pada pasien remaja dengan disabilitas intelektual di Rumah Sakit Jiwa Provinsi Jawa Barat. Penelitian farmakoekonomi pada topik ini penting dilakukan karena adanya peningkatan kebutuhan anggaran obat-obatan psikotropika sementara anggaran yang tersedia masih terbatas. Tujuan penelitian ini adalah untuk mengetahui profil penggunaan obat-obatan psikotropika pada pasien remaja dengan disabilitas intelektual di rumah sakit tersebut pada kurun waktu tahun 2015-2017 dan untuk mengetahui biaya obat-obatan psikotropika yang paling rendah pada segmen drug utilization $90 \%$ (DU 90\%) pada tahun-tahun tersebut. Studi observasional deskriptif secara retrospektif dan prospektif dilakukan untuk mengumpulkan data dari rekam medik. Metode Anatomical Therapeutic Chemical Classification with Defined Daily Dose (ATC/DDD) dan Analisis Minimalisasi Biaya (AMiB) digunakan untuk mengetahui profil penggunaan obat-obatan dan untuk menganalisis biaya obat-obatan yang paling rendah selama kurun waktu tersebut. Pada penelitian ini, terdapat penggunaan 33 jenis obat psikotropika (19 jenis pada tahun 2015, 22 jenis pada tahun 2016 dan 29 jenis pada tahun 2017). Cost of DU 90\% pada tahun 2015-2017 secara berurutan yaitu 55,11\%, $68,73 \%$ dan 93,81\%, sedangkan cost/DDD segmen DU 90\% secara berurutan yaitu Rp6.258, Rp 7.447, dan Rp8.803. Biaya obat-obatan psikotropika pada tahun 2015 merupakan biaya terendah selama 2015-2017.
\end{abstract}

Kata kunci: Analisis minimalisasi biaya, disabilitas intelektual, psikotropika

\section{Cost-Minimization Analysis of Psychotropic Drug in Adolescent Patients with Intellectual Disability in Mental Hospital of West Java 2015-2017}

\begin{abstract}
Psychotropic drugs were one of the the most widely used drugs in adolescent patients with intellectual disability in Mental Hospital of West Java. Pharmacoeconomic study on this topic is important because budget for psychotropic drugs need is increased while the available budget is still limited. The objective of this study was to analyze the utilization profile of psychotropic drugs in adolescents with intellectual disability during a time horizon of 2015-2017 and to investigate the lowest cost of psychotropic drugs in a segment of drug utilization 90\% (DU 90\%) during those years. Retrospective and prospective observational studies were applied to collect patients' medical record data. The Anatomical Therapeutic Chemical Classification System with Defined Daily Dose (ATC/DDD) and Cost Minimization Analysis (CMA) methods were applied to analyse the utilization profile of drugs and to investigate the lowest cost of drugs during the time horizon, respectively. In this study, there were 33 types of psychotropic drugs used (19 types in 2015, 22 types in 2016, and 29 types in 2017). The costs of DU 90\% during 2015-2017 were estimated to be $55.11 \%, 68.73 \%$ and $93.81 \%$ in 2015,2016 and 2017 , respectively, while the costs per DDD in DU 90\% segment were estimated to be IDR 6,258, IDR 7,447, and IDR 8,803, respectively. In particular, cost of psychotropic drugs in 2015 was considered to be the lowest cost during 2015-2017.
\end{abstract}

Keywords: Cost-minimization analysis, intellectual disability, psychotropic drug

Korespondensi: Ice L. Nur, S.Si., Apt., Program Studi Magister Farmasi Klinik, Universitas Padjadjaran, Sumedang, Jawa Barat 45363, Indonesia, email: athailannur@gmail.com

Naskah diterima: 15 Mei 2018, Diterima untuk diterbitkan: 15 Agustus 2018, Diterbitkan: 1 September 2018 


\section{Pendahuluan}

Disabilitas intelektual merupakan disabilitas yang ditandai dengan suatu keterbatasan yang signifikan dalam fungsi intelektual (mengacu pada kemampuan mental secara umum seperti penalaran, belajar, pemecahan masalah, dan sebagainya) dan perilaku adaptif mencakup banyak keterampilan sosial dan keterampilan praktis sehari-hari. Disabilitas ini terjadi sebelum usia 18 tahun. ${ }^{1}$ Prevalensi disabilitas intelektual berdasarkan sebuah meta analisis adalah sekitar $1 \%$ (yaitu $1,64 \%$ di negaranegara dengan penghasilan rendah, $1,59 \%$ di negara-negara dengan penghasilan menengah dan $0,92 \%$ di negara-negara berpenghasilan tinggi). ${ }^{2}$ Di Indonesia belum terdapat data prevalensi disabilitas intelektual, akan tetapi berdasarkan survei sosial ekonomi nasional (Susenas) pada tahun 2012, diperoleh bahwa prevalensi disabilitas sebesar 2,45\%, dengan disabilitas didefinisikan oleh ketidakmampuan melakukan suatu kegiatan/aktivitas tertentu seperti layaknya orang normal yang diakibatkan oleh kondisi impairment (ketidakmampuan/ kehilangan), berhubungan dengan usia dan masyarakat. $^{3}$

Seseorang dengan disabilitas intelektual rentan mengalami gangguan psikis seperti skizofrenia, bipolar dan kecemasan. ${ }^{4}$ Pada anak-anak dan remaja yang memiliki disabilitas intelektual, $30-50 \%$ teridentifikasi memiliki gangguan penyerta berupa gangguan jiwa. ${ }^{5}$ Intervensi perlu dilakukan untuk mencegah keadaan menjadi lebih buruk, salah satunya dengan pemberian farmakoterapi psikotropika yang bertujuan untuk mengobati gangguan jiwa secara umum maupun untuk mengelola gangguan perilaku yang menantang seperti agresivitas dan iritabilitas. ${ }^{6}$ Psikotropika yang paling sering diresepkan adalah antipsikotik, diikuti oleh antidepresan, antiepilepsi atau moodstabilizer dan stimulan. ${ }^{7}$

Farmakoterapi psikotropika yang diberikan pada kasus disabilitas intelektual memiliki bukti efektivitas menguntungkan. ${ }^{8}$ Namun demikian, selain bukti efektivitas, diperlukan data hasil penelitian aspek farmakoekonomi. Kurangnya penelitian aspek ekonomi pada kasus disabilitas intelektual menjadi hambatan dalam pengambilan kebijakan dan keputusan teknis bagi pasien disabilitas intelektual. ${ }^{9}$ Biaya ekonomi terkait gangguan mental, termasuk pula disabilitas intelektual, paling banyak tercermin dalam pengeluaran langsung oleh perorangan, perusahaan, dan juga pemerintah untuk pengobatan. ${ }^{10}$ Selain memerlukan biaya langsung pengobatan, disabilitas intelektual juga memerlukan biaya tidak langsung yang besar. Penelitian di Australia menunjukkan bahwa disabilitas intelektual memerlukan biaya yang tinggi terutama bagi keluarga, meliputi biaya peluang akibat kehilangan waktu sehingga keluarga menderita kerugian yang besar. ${ }^{11}$

Psikotropika adalah obat-obatan yang paling banyak digunakan di dalam penatalayanan pengobatan pasien-pasien gangguan jiwa di RS Jiwa Provinsi Jawa Barat termasuk pasien Kesehatan Jiwa Anak dan Remaja (Keswara) berusia 0-18 tahun. Berdasarkan data yang diperoleh dari Instalasi Rekam Medik tahun 2016, total pasien Keswara yang dirawat adalah 150 pasien, dan sebanyak 72 pasien (48\%) didiagnosis memiliki disabilitas intelektual yang merupakan diagnosis terbanyak. Pasien remaja yang berusia 12-18 tahun merupakan mayoritas dari pasien Keswara, yakni 146 pasien $(97,3 \%)$.

Penatalayanan terapi psikotropika pada remaja dengan disabilitas intelektual telah lama dilakukan di RS Jiwa Provinsi Jawa Barat. Sebagai rumah sakit pusat rujukan kesehatan jiwa di Jawa Barat, RS Jiwa Provinsi Jawa Barat mengembangkan pelayanan Keswara baik rawat jalan maupun rawat inap. Dengan bertambahnya jumlah pasien Keswara yang dirawat, kebutuhan obat psikotropika baik jenis dan jumlahnya pun akan meningkat pula. Ketersediaan anggaran yang terbatas adalah hal yang menjadi perhatian, dan oleh karena 
itu diperlukan suatu analisis pemanfaatan obat psikotropika tersebut termasuk analisis dari aspek farmakoekonomi, khususnya Analisis Minimalisasi Biaya (AMiB).

Berdasarkan pada latar belakang di atas, penelitian ini sangat penting dalam evaluasi pemanfaatan obat untuk mengetahui profil penggunaan obat-obatan psikotropika serta analisis farmakoekonomi yaitu $\mathrm{AMiB}$, dengan tujuan untuk mengetahui biaya penggunaan obat-obat psikotropika yang paling minimal berdasarkan biaya segmen DU 90\% dalam 3 tahun terakhir (tahun 2015-2017), di RS Jiwa Provinsi Jawa Barat.

\section{Metode}

Penelitian ini merupakan studi observasional deskriptif dan analisis minimalisasi biaya dengan data yang diambil secara retrospektif dan prospektif terhadap populasi data pasien remaja dengan disabilitas intelektual yang dirawat di RS Jiwa Provinsi Jawa Barat pada tahun 2015 hingga 2017. Sampel penelitian diambil secara total sampling dengan kriteria data pasien remaja yang berusia 12-18 tahun, memiliki diagnosis retardasi mental (nama lain dari disabilitas intelektual sebelumnya) menurut kriteria international classification of diseases $10^{\text {th }}$ (ICD-10) dan diagnostic and statistical manual of mental disorders $4^{\text {th }}$ (DSM-IV-TR) pada Axis II, mendapatkan terapi obat psikotropika dan dirawat dalam kurun waktu 2015, 2016 atau 2017.

Kriteria remaja dalam penelitian ini merujuk pada kategori remaja yang berdasar pada fase perkembangan menurut Havighurst (1972). ${ }^{12}$ Hal ini berdasar atas pertimbangan bahwa di RS Jiwa Provinsi Jawa Barat, asesmen riwayat perkembangan merupakan salah satu aspek asesmen riwayat psikiatri yang dilakukan oleh dokter pemeriksa terhadap keluarga pasien Keswara, dan berdasarkan kebijakan di rumah sakit tersebut, pasien yang berusia di atas 18 tahun dirawat di ruang perawatan dewasa.
Data penelitian diperoleh dari rekam medik pasien dan Sistem Informasi Manajemen Rumah Sakit, yang meliputi data karakteristik pasien (nomor rekam medik, jenis kelamin, usia dan lama hari rawat), data klinis pasien yaitu diagnosis medis, data penggunaan obat (jenis obat, kekuatan sediaan dan volume), serta data keuangan (harga obat psikotropika). Persetujuan etik telah diperoleh dari Komite Etik Penelitian Kesehatan Rumah Sakit Jiwa Provinsi Jawa Barat dengan nomor izin 800/ 18549/RSJ.

Analisis penggunaan obat berdasarkan The Anatomical Therapeutic Chemical Classification System with Defined Daily Dose (ATC/DDD) pada tahun 2015-2017

Analisis ini dilakukan dengan mengidentifikasi seluruh jenis obat-obatan psikotropika yang digunakan pasien remaja dengan disabilitas intelektual pada masing-masing tahun dengan menggunakan sistem ATC/DDD.

Analisis Minimalisasi Biaya (AMiB) Analisis minimalisasi biaya dilakukan berdasar perspektif penyedia layanan kesehatan (health care provider) dengan membandingkan biaya penggunaan obat-obatan psikotropika pada tahun 2015, 2016 dan 2017 dilihat dari cost of drug utilization (DU) 90\% dan cost/DDD DU 90\%. Perhitungan DDD dan DDD/100 beddays dilakukan guna menyusun daftar obat-obat psikotropika yang masuk segmen DU 90\%.

DDD dan DDD/100 bed-days

Nilai DDD ditentukan dari jumlah penggunaan masing-masing obat psikotropika (dalam satuan miligram) yang dikonsumsi oleh pasien remaja dengan disabilitas intelektual pada masingmasing tahun. Nilai DDD dihitung dengan menggunakan persamaan $1:^{13}$

DDD obat tertentu $=\underline{\text { Kekuatan sediaan }(\mathrm{mg})} \times$ kuantitas Nilai DDD WHO

Sementara itu, DDD/100 bed-days dihitung menggunakan persamaan $2:^{13}$ 
$\mathrm{DDD} / 100$ bed-days $=\underline{\mathrm{DDD} \text { total masing-masing obat } \mathrm{x} 100}$ Total hari rawat

Perhitungan DDD/100 bed-days digunakan dengan pertimbangan bahwa populasi dalam penelitian ini adalah pasien rawat inap. Hal ini mengacu pada WHO Collaborating Centre for Drug Statistics Methodology bahwa angka konsumsi obat dapat disajikan sebagai angka DDDs/1000 penduduk/hari, atau DDD/100 bed-days dipertimbangkan untuk penggunaan obat di rumah sakit. ${ }^{14}$

\section{Penentuan DU 90\%}

Penentuan DU 90\% dilakukan dengan cara mengonversikan masing-masing DDD/100 beddays obat psikotropika menjadi persentase (\%) dari pemakaian obat. Masing-masing \% pemakaian obat diurutkan dari \% pemakaian tertinggi sampai dengan terendah, kemudian $\%$ pemakaian dijumlahkan dari pemakaian tertinggi dan dipotong pada pemakaian $90 \%$, sehingga dapat ditentukan obat-obatan yang termasuk ke dalam segmen DU 90\%. ${ }^{15}$

\section{Perhitungan cost of DU $90 \%$ dan cost/DDD DU 90\%}

Cost of DU $90 \%$ dihitung dengan menentukan total harga dari biaya obat-obatan psikotropika yang termasuk ke dalam segmen DU 90\% dibandingkan dengan total harga keseluruhan obat-obatan psikotropika. Cost of DU 90\% ditampilkan dalam persentase (\%), sedangkan Cost/DDD DU $90 \%$ dihitung terhadap obatobatan psikotropika yang masuk segmen DU 90\% dengan cara menentukan total harga obatobatan psikotropika yang termasuk ke dalam segmen DU $90 \%$ dibagi dengan total DDD obat-obatan psikotropika yang termasuk ke dalam segmen DU 90\%.

\section{Hasil}

Karakteristik populasi

Data total pasien dengan kategori anak dan remaja (usia 0-18 tahun) yang dirawat pada tahun 2015-2017 yakni berjumlah 380 orang (51 orang pada tahun 2015,150 orang pada tahun 2016 dan 179 orang pada tahun 2017), sedangkan data populasi pasien remaja usia 12-18 tahun dengan disabilitas intelektual pada tahun 2015-2017 adalah 149 orang, terdiri dari 19 orang (laki-laki=12 atau 63,2\% dan perempuan $=7$ atau $36,8 \%$ ) pada tahun 2015, 54 orang (laki-laki=39 atau $72,2 \%$ dan perempuan $=15$ atau $27,8 \%$ ) pada tahun 2016 dan 76 orang (laki-laki=64 atau 84,2\% dan perempuan=12 atau 15,8\%) pada tahun 2017 . Seluruh data populasi ini memenuhi kriteria inklusi dan tidak ada yang dieksklusi.

Profil penggunaan psikotropika berdasarkan ATC/DDD

Dari tahun 2015 hingga 2017, diperoleh data penggunaan 33 jenis obat-obat psikotropika yang seluruhnya sudah memiliki kode pada sistem ATC dan memiliki nilai DDD. Obat psikotropika yang digunakan pada tahun 2015 berjumlah 19 jenis, dan semakin meningkat jumlahnya pada tahun 2016 dan 2017, yaitu 22 dan 29 jenis secara berurut. Tabulasi data jenis psikotropika yang digunakan pada tahun 2015-2017 berdasarkan sistem ATC/DDD terdapat pada Tabel 1.

Analisis minimalisasi biaya Hasil perhitungan DDD dan DDD/100 beddays obat-obatan psikotropika pada tahun 2015-2017 terdapat pada Tabel 2, sedangkan daftar obat-obatan psikotropika yang masuk ke dalam segmen DU 90\% terdapat pada Tabel 3. Tiga jenis obat psikotropika yang paling banyak digunakan berdasar DDD, DDD/100 bed-days dan DU 90\% pada tahun 2015 secara berurutan adalah risperidon, triheksifenidil dan haloperidol. Sementara itu, 3 jenis obat yang paling banyak digunakan pada tahun 2016 memiliki kesamaan urutan dengan tahun 2017, yaitu risperidon, triheksifenidil dan asam valproat.

Cost of DU 90\% tahun 2015, 2016 dan 
Tabel 1 Penggunaan Obat Berdasarkan ATC/DDD pada Tahun 2015-2017

\begin{tabular}{|c|c|c|c|c|c|c|c|}
\hline \multirow{2}{*}{ No } & \multirow{2}{*}{ Nama Obat } & \multirow{2}{*}{ Kode ATC } & \multirow{2}{*}{ Rute } & \multirow{2}{*}{$\begin{array}{c}\text { DDD* } \\
\text { (mg) }\end{array}$} & \multicolumn{3}{|c|}{ Tahun Penggunaan } \\
\hline & & & & & 2015 & 2016 & 2017 \\
\hline 1 & Alprazolam & N05BA12 & Oral & 1 & & & $\sqrt{ }$ \\
\hline 2 & Amitriptilin & N06AA09 & Oral & 75 & & & $\sqrt{ }$ \\
\hline 3 & Aripiprazol & N05AX12 & Oral & 15 & $\sqrt{ }$ & $\sqrt{ }$ & $\sqrt{ }$ \\
\hline 4 & Aripiprazol & N05AX12 & Parenteral & 15 & $\sqrt{ }$ & & \\
\hline 5 & Asam valproat & N03AG01 & Oral & 1500 & $\sqrt{ }$ & $\sqrt{ }$ & $\sqrt{ }$ \\
\hline 5 & Atomoksetin & N06BA09 & Oral & 80 & $\sqrt{ }$ & & \\
\hline 7 & Diazepam & N05BA01 & Oral & 10 & $\sqrt{ }$ & & $\sqrt{ }$ \\
\hline 8 & Diazepam & N05BA01 & Parenteral & 10 & $\sqrt{ }$ & $\sqrt{ }$ & $\sqrt{ }$ \\
\hline 9 & Diazepam & N05BA01 & Rektal & 10 & & $\sqrt{ }$ & $\sqrt{ }$ \\
\hline 10 & Donepezil & N06DA02 & Oral & 7,5 & & & $\sqrt{ }$ \\
\hline 11 & Fenitoin & N03AB02 & Oral & 300 & $\sqrt{ }$ & $\sqrt{ }$ & $\sqrt{ }$ \\
\hline 12 & Fenobarbital & N03AA02 & Oral & 100 & $\sqrt{ }$ & $\sqrt{ }$ & $\sqrt{ }$ \\
\hline 13 & Flufenazin & N05AB02 & Par. depot & 1 & & $\sqrt{ }$ & $\sqrt{ }$ \\
\hline 14 & Fluoksetin & N06AB03 & Oral & 20 & $\sqrt{ }$ & $\sqrt{ }$ & $\sqrt{ }$ \\
\hline 15 & Gabapentin & N03AX12 & Oral & 1800 & & & $\sqrt{ }$ \\
\hline 16 & Haloperidol & N05AD01 & Oral & 8 & $\sqrt{ }$ & $\sqrt{ }$ & $\sqrt{ }$ \\
\hline 17 & Haloperidol & N05AD01 & Parenteral & 8 & $\sqrt{ }$ & $\sqrt{ }$ & $\sqrt{ }$ \\
\hline 18 & Haloperidol & N05AD01 & Par. depot & 3,3 & & $\sqrt{ }$ & \\
\hline 19 & Karbamazepin & N03AF01 & Oral & 1000 & & & $\sqrt{ }$ \\
\hline 20 & Klobazam & N05BA09 & Oral & 10 & $\sqrt{ }$ & $\sqrt{ }$ & $\sqrt{ }$ \\
\hline 21 & Klorpromazin & N05AA01 & Oral & 300 & $\sqrt{ }$ & & $\sqrt{ }$ \\
\hline 22 & Klozapin & N05AH02 & Oral & 300 & $\sqrt{ }$ & $\sqrt{ }$ & $\sqrt{ }$ \\
\hline 23 & Lorazepam & N05BA06 & Oral & 2,5 & $\sqrt{ }$ & $\sqrt{ }$ & $\sqrt{ }$ \\
\hline 24 & Metilfenidat & N06BA04 & Oral & 30 & & $\sqrt{ }$ & $\sqrt{ }$ \\
\hline 25 & Okskarbazepin & N03AF02 & Oral & 1000 & & & $\sqrt{ }$ \\
\hline 26 & Olanzapin & N05AH03 & Oral & 10 & $\sqrt{ }$ & $\sqrt{ }$ & $\sqrt{ }$ \\
\hline 27 & Olanzapin & N05AH03 & Parenteral & 10 & $\sqrt{ }$ & $\sqrt{ }$ & $\sqrt{ }$ \\
\hline 28 & Paliperidon & N05AX13 & Par. depot & 2,5 & & $\sqrt{ }$ & \\
\hline 29 & Quetiapin & N05AH04 & Oral & 400 & & & $\sqrt{ }$ \\
\hline 30 & Risperidon & N05AX08 & Oral & 5 & $\sqrt{ }$ & $\sqrt{ }$ & $\sqrt{ }$ \\
\hline 31 & Sertralin & N06AB06 & Oral & 50 & & $\sqrt{ }$ & $\sqrt{ }$ \\
\hline 32 & Trifluoferazin & N05AB06 & Oral & 20 & & $\sqrt{ }$ & $\sqrt{ }$ \\
\hline 33 & Triheksifenidil & N04AA01 & Oral & 10 & $\sqrt{ }$ & $\sqrt{ }$ & $\sqrt{ }$ \\
\hline
\end{tabular}

Keterangan:

*Berdasarkan https://www.whocc.no/atc_ddd_index/

$\sqrt{ }=$ digunakan pada tahun tersebut 
Tabel 2 Hasil Perhitungan DDD dan DDD/100 Bed-Days Obat-obatan Psikotropika pada Tahun 2015-2017

\begin{tabular}{|c|c|c|c|c|c|c|c|c|}
\hline \multirow{2}{*}{ No } & \multirow{2}{*}{ Nama Obat } & \multirow{2}{*}{ Rute } & \multicolumn{3}{|c|}{ DDD } & \multicolumn{3}{|c|}{ DDD/100 bed-days } \\
\hline & & & 2015 & 2016 & 2017 & 2015 & 2016 & 2017 \\
\hline 1 & Alprazolam & Oral & & & 47,5 & & & 2,7 \\
\hline 2 & Amitriptilin & Oral & & & 9,3 & & & 0,5 \\
\hline 3 & Aripiprazol & Oral & 29,7 & 75 & 138 & 8,2 & 7 & 7,9 \\
\hline 4 & Aripiprazol & Parenteral & 7,2 & & & 2 & & \\
\hline 5 & Asam valproat & Oral & 64,7 & 314,2 & 336,5 & 17,9 & 29,5 & 19,2 \\
\hline 6 & Atomoksetin & Oral & 2 & & & 0,6 & & \\
\hline 7 & Diazepam & Oral & 21 & & 1,4 & 5,8 & & 0,1 \\
\hline 8 & Diazepam & Parenteral & 1 & 1 & 22 & 0,3 & 0,1 & 1,3 \\
\hline 9 & Diazepam & Rektal & & 5 & 3 & & 0,5 & 0,2 \\
\hline 10 & Donepezil & Oral & & & 105,3 & & & 6 \\
\hline 11 & Fenitoin & Oral & 42,3 & 30,2 & 60,5 & 11,7 & 2,8 & 3,4 \\
\hline 12 & Fenobarbital & Oral & 54,8 & 92,7 & 114,6 & 15,2 & 8,7 & 6,5 \\
\hline 13 & Flufenazin & Parenteral depot & & 50 & 275 & & 4,7 & 15,7 \\
\hline 14 & Fluoksetin & Oral & 14 & 40 & 156 & 3,9 & 3,8 & 8,9 \\
\hline 15 & Gabapentin & Oral & & & 15,2 & & & 0,9 \\
\hline 16 & Haloperidol & Oral & 140,9 & 31,9 & 121,6 & 39 & 3 & 6,9 \\
\hline 17 & Haloperidol & Parenteral & 8,8 & 15 & 18,1 & & 7,8 & \\
\hline 18 & Haloperidol & Parenteral depot & & 83,3 & & 2,4 & 1,4 & 1 \\
\hline 19 & Karbamazepin & Oral & & & 12 & & & 0,7 \\
\hline 20 & Klobazam & Oral & 31 & 134 & 76,1 & 8,6 & 12,6 & 4,3 \\
\hline 21 & Klorpromazin & Oral & 14,7 & & 1,5 & 4,1 & & 0,1 \\
\hline 22 & Klozapin & Oral & 18,5 & 60,3 & 95,8 & 5,1 & 5,7 & 5,5 \\
\hline 23 & Lorazepam & Oral & 111 & 43,4 & 60,8 & 30,7 & 4,1 & 3,5 \\
\hline 24 & Metilfenidat & Oral & & 25,3 & 62,3 & & 2,4 & 3,6 \\
\hline 25 & Okskarbazepin & Oral & & & 2,7 & & & 0,2 \\
\hline 26 & Olanzapin & Oral & 41 & 85,5 & 17,5 & 11,4 & 8 & 1 \\
\hline 27 & Olanzapin & Parenteral & 4 & 29 & 76,5 & 1,1 & 2,7 & 4,4 \\
\hline 28 & Paliperidon & Parenteral depot & & 10 & & & 0,9 & \\
\hline 29 & Quetiapin & Oral & & & 12 & & & 0,7 \\
\hline 30 & Risperidon & Oral & 288,4 & 1119,6 & 1969,5 & 79,9 & 105,1 & 112,2 \\
\hline 31 & Sertralin & Oral & & 11 & 34,5 & & 1 & 2 \\
\hline 32 & Trifluoferazin & Oral & & 10,9 & 19,8 & & 1 & 1,1 \\
\hline 33 & Triheksifenidil & Oral & 188 & 435,5 & 927 & 52,1 & 40,9 & 52,8 \\
\hline
\end{tabular}


Tabel 3 Drug Utilization 90\% (DU 90\%) Psikotropika Tahun 2015-2017

\begin{tabular}{|c|c|c|c|c|c|c|}
\hline \multirow[b]{2}{*}{ No. } & \multicolumn{2}{|c|}{2015} & \multicolumn{2}{|c|}{2016} & \multicolumn{2}{|c|}{2017} \\
\hline & Nama Obat & $\begin{array}{c}\text { Persentase } \\
\text { DDD/100 } \\
\text { bed-days }(\%)\end{array}$ & Nama Obat & $\begin{array}{c}\text { Persentase } \\
\text { DDD/100 } \\
\text { bed-days }(\%)\end{array}$ & Nama Obat & $\begin{array}{c}\text { Persentase } \\
\text { DDD/100 } \\
\text { bed-days }(\%)\end{array}$ \\
\hline 1 & Risperidon & 26,63 & Risperidon & 41,42 & Risperidon & 41,1 \\
\hline 2 & Triheksifenidil & 17,36 & Triheksifenidil & 16,11 & Trihexyphenidil & 19,34 \\
\hline 3 & Haloperidol & 13,02 & Asam valproat & 11,62 & Asam valproat & 7,02 \\
\hline 4 & Lorazepam & 10,25 & Klobazam & 4,96 & $\begin{array}{l}\text { Flufenazin } \\
\text { (par. depot) }\end{array}$ & 5,74 \\
\hline 5 & Asam valproat & 5,97 & Fenobarbital & 3,43 & Fluoksetin & 3,26 \\
\hline 6 & Fenobarbital & 5,06 & Olanzapin & 3,16 & Aripiprazol & 2,88 \\
\hline 7 & Fenitoin & 3,91 & $\begin{array}{l}\text { Haloperidol } \\
\text { (par. depot) }\end{array}$ & 3,08 & Haloperidol & 2,54 \\
\hline 8 & Olanzapin & 3,79 & Aripiprazol & 2,77 & Fenobarbital & 2,39 \\
\hline 9 & Klobazam & 2,86 & Klozapin & 2,23 & Donepezil & 2,2 \\
\hline 10 & Aripiprazol & 2,74 & $\begin{array}{l}\text { Flufenazin } \\
\text { (parenteral) }\end{array}$ & 1,85 & Klozapin & 2 \\
\hline 11 & & & & & $\begin{array}{l}\text { Olanzapin } \\
\text { (parenteral) }\end{array}$ & 1,6 \\
\hline
\end{tabular}

Keterangan: Persentase DDD/100 bed-days merupakan hasil perhitungan DDD/100 bed-days masing-masing obat psikotropika yang dipersentasekan terhadap nilai total DDD/100 bed-days seluruh obat psikotropika

2017 secara berurutan adalah $55,11 \%, 68,73 \%$ dan 93,81\%. Tahun 2015 memiliki cost of DU 90\% terendah, hal ini memiliki makna bahwa besar biaya yang diperlukan untuk penggunaan obat-obatan psikotropika pada segmen DU $90 \%$ tahun 2015 adalah $55,11 \%$ dari total biaya obat psikotropika yang digunakan pada pasien rawat inap remaja dengan disabilitas intelektual. Cost of DU 90\% penggunaan obat psikotropika tahun 2015-2017 terdapat pada Gambar 1.

Cost/DDD DU 90\% atau besarnya biaya yang diperlukan untuk 1 DDD obat-obatan psikotropika yang berada pada segmen DU

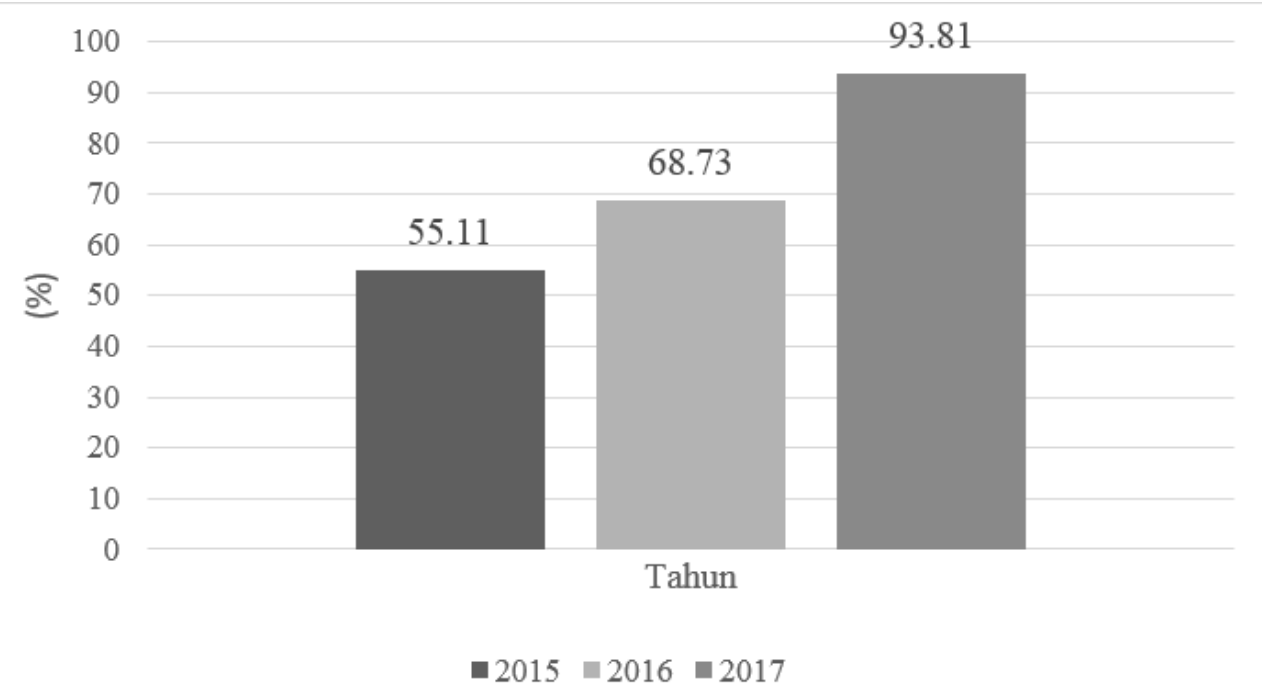

Gambar 1 Cost of DU 90\% Tahun 2015-2017 
90\% tahun 2015, 2016 dan 2017 secara berurut adalah Rp6.258, Rp7.447 dan Rp8.883. Cost/ DDD DU 90\% penggunaan psikotropika pada tahun 2015-2017 terdapat pada Gambar 2.

\section{Pembahasan}

Pada populasi remaja yang memiliki disabilitas intelektual di RS Jiwa Provinsi Jawa Barat tahun 2015 sampai dengan 2017, berdasarkan pada jenis kelaminnya disabilitas intelektual lebih banyak ditemukan pada remaja laki-laki dibandingkan perempuan. Hasil penelitian ini serupa dengan penelitian-penelitian sebelumnya yang menyatakan bahwa disabilitas intelektual lebih banyak terjadi pada laki-laki. ${ }^{16-18}$

Secara garis besar, penggolongan obat psikotropika yang digunakan pada tahun 2015 hingga tahun 2017 adalah golongan antiepilepsi (N03), antiparkinson (N04), psikoleptik (N05) terdiri dari antipsikotik (N05A) dan ansiolitik (N05B) serta golongan psikoanaleptik (N06) yang di antaranya adalah antidepresan (N06A), psikostimulan, agen yang digunakan untuk Attention Deficit Hyperactivity Disorder dan notropik (N06B), serta antidemensia (N06D).

DDD adalah dosis pemeliharaan rata-rata setiap hari yang digunakan pada orang dewasa untuk indikasi utama. ${ }^{14}$ Pada penelitian yang dilakukan terhadap remaja dengan disabilitas intelektual ini, DDD digunakan sebagai suatu ukuran yang digunakan untuk mengevaluasi penggunaan obat psikotropika pada populasi tersebut dari tahun ke tahun yaitu 2015 sampai dengan 2017, dengan alasan belum terdapat referensi mengenai DDD khusus untuk anak dan remaja. Hal ini disebabkan World Health Organization Collaborating Centre for Drug Statistics Methodology masih menyimpulkan bahwa DDD untuk pediatri masih belum mapan untuk ditetapkan, karena rekomendasi dosisnya tidak bisa digeneralisasi dan akan berbeda berdasarkan usia dan berat badan anak. ${ }^{14}$

Hasil perhitungan DDD/100 bed-days menggambarkan jumlah DDD/100 pasienhari rawat dan dapat diubah menjadi rata-rata penggunaan obat berdasarkan DDD/pasien/ hari, sehingga dapat diketahui dosis rata-rata per pasien per hari dari masing-masing obat psikotropika. Risperidon merupakan obat psikotropika yang paling banyak digunakan pada tahun 2015, 2016 dan 2017 yaitu sebanyak 79,89 DDD/100 bed-days, 105,13 DDD/100 bed-days dan 112,22 DDD/100 bed-days. Hal ini menunjukkan bahwa rata-rata risperidon yang digunakan oleh pasien remaja dengan disabilitas intelektual pada tahun 2015 adalah $0,8 \mathrm{DDD} /$ pasien/hari $(0,8 \times 5 \mathrm{mg}=4 \mathrm{mg} /$ pasien/

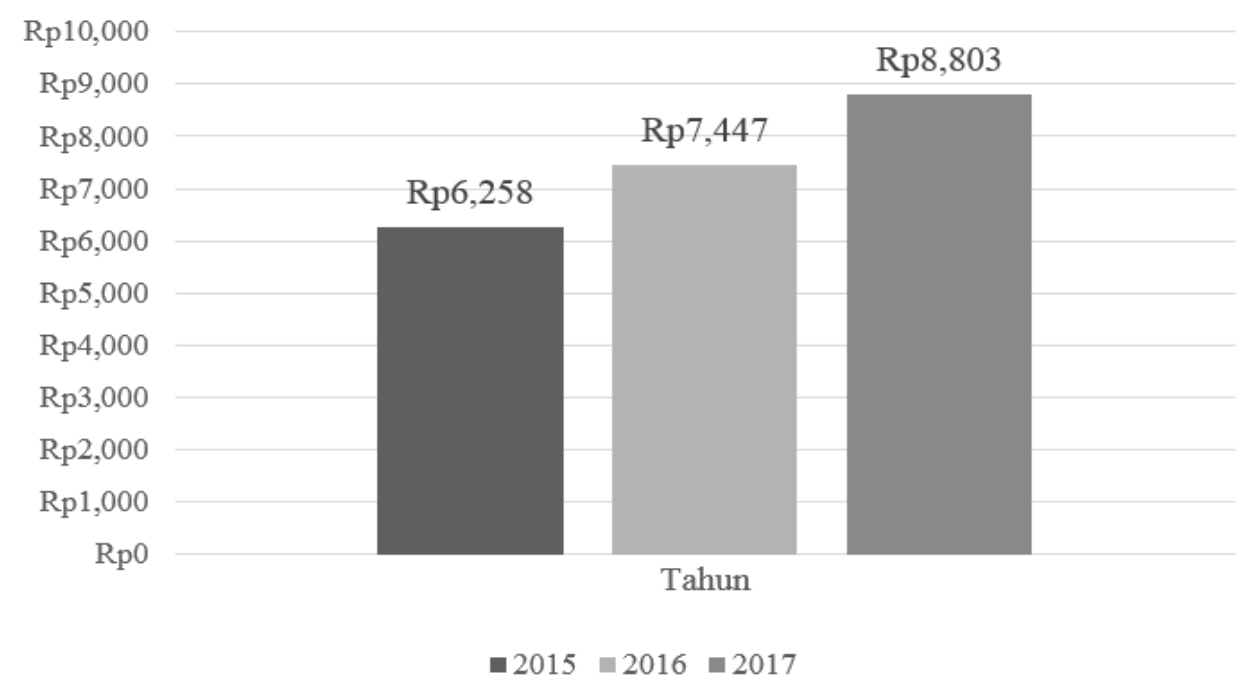

Gambar 2 Cost/DDD DU 90\% Tahun 2015-2017 
hari), sedangkan pada tahun 2016 adalah $1,05 \mathrm{DDD} /$ pasien/hari $(1,05 \times 5 \mathrm{mg}=5,25 \mathrm{mg} /$ pasien/hari) dan pada tahun 2017 adalah 1,12 $\mathrm{DDD} /$ pasien/hari $(1,12 \times 5 \mathrm{mg}=5,6 \mathrm{mg} /$ pasien/ hari). Peningkatan rata-rata dosis risperidon yang digunakan pada pasien remaja dengan disabilitas intelektual dari tahun ke tahun kemungkinan disebabkan oleh banyak faktor, salah satu di antaranya adalah akibat terjadi perubahan pola dari penggunaan obat yang semula adalah antipsikotik tipikal haloperidol yang kemudian menjadi risperidon. Jumlah penggunaan haloperidol semua sediaan (oral, parenteral dan parenteral depot) menurun yaitu 41,5 DDD/100 bed-days pada tahun 2015, 12,2 DDD/100 bed-days pada tahun 2016 dan 8 DDD/bed-days pada tahun 2017. Perubahan pola penggunaan obat ini dapat dipengaruhi oleh adanya suatu pertimbangan bahwa obat antipsikotik atipikal menginduksi efek samping ekstrapiramidal lebih sedikit dibanding haloperido $1^{19}$ atau semakin baiknya tingkat ketersediaan obat risperidon dari tahun ke tahun, ditambah dengan adanya penurunan harga obat risperidon dari tahun 2015 hingga 2017, seperti risperidon $2 \mathrm{mg}$ tablet tahun 2015 hingga 2017 (secara berurutan yaitu Rp1290, Rp800 dan Rp539) dan risperidon 3 mg tablet tahun 2015 hingga 2017 (secara berurutan yaitu Rp2560, Rp1760 dan Rp959), sehingga sangat mungkin jumlah obat yang disediakan oleh Rumah Sakit Jiwa semakin meningkat.

DDD risperidon menurut WHO adalah 5 $\mathrm{mg}$ /hari pada orang dewasa (berat badan 70 $\mathrm{kg}$ ) yang digunakan untuk indikasi utama. Pada penelitian ini, risperidon digunakan pada pasien remaja dengan disabilitas intelektual dengan atau tanpa gangguan klinis utama psikotik, dengan berat badan rata-rata lazimnya kurang dari 70 kg. Pada tahun 2016 dan 2017 , rata-rata dosis risperidon yang digunakan pasien remaja dengan disabilitas intelektual sudah lebih dari 1 DDD (>5 mg/pasien/hari) hal ini kemungkinan disebabkan oleh adanya respon yang kurang baik terhadap risperidon sehingga rata-rata dosis penggunaan menjadi lebih besar. Selain penilaian respon terapi, pada penggunaan dosis obat yang lebih besar perlu diperhatikan risiko efek samping yang lebih besar.

Antipsikotik merupakan obat yang paling banyak digunakan pada pasien remaja dengan disabilitas intelektual. Sebuah penelitian potong lintang multinasional pada pasien disabilitas intelektual menunjukkan bahwa penggunaan psikotropika adalah $90 \%$, terutama antipsikotik yakni sebesar $74 \% .{ }^{20}$ Antipsikotik, terutama risperidon, dinilai efektif dalam mengurangi gangguan perilaku pada anak-anak dengan disabilitas intelektual. ${ }^{21}$

Beberapa penelitian sebelumnya mengenai bukti efektivitas risperidon pada pasien anak dan remaja dengan disabilitas intelektual dengan atau tanpa gangguan penyerta menunjukkan bahwa obat tersebut mempunyai efektivitas dalam memperbaiki gangguan perilaku. ${ }^{22-24}$ Selain efektivitas yang menguntungkan untuk mengurangi perilaku menantang dalam jangka pendek pada anak-anak dengan disabilitas intelektual, antipsikotik juga memiliki risiko efek samping yang berupa sedasi, peningkatan prolaktin dan peningkatan berat badan yang signifikan. ${ }^{25}$ Pada penelitian lain, dilaporkan ada efek samping metabolisme, endokrinologi dan kardiovaskular dari antipsikotik atipikal. Efek samping metabolik merupakan efek samping yang paling sering dan merepotkan seiring dengan semakin meningkatnya bukti risiko diabetes melitus tipe II. ${ }^{26}$

Pemberian obat antipsikotik terhadap pasien yang memiliki disabilitas intelektual perlu lebih dipantau karena lebih rentan terhadap risiko efek samping bila dibandingkan dengan yang tidak memiliki disabilitas intelektual. Sebuah penelitian kohort menunjukkan bukti asumsi tersebut, yaitu pasien yang memiliki disabilitas intelektual lebih rentan mengalami gangguan pergerakan, parkinsonisme, akathisia dan neuroleptic malignant syndrome dibandingkan pasien tanpa disabilitas intelektual. ${ }^{27}$ 
Efek samping dari penggunaan antipsikotik kemungkinan dapat meningkatkan biaya yang diperlukan selama perawatan, contohnya yaitu biaya obat yang digunakan untuk mengatasi efek samping tersebut, untuk biaya pemeriksaan penunjang, dan penambahan biaya hari rawat yang memerlukan observasi yang lebih intensif dari tenaga kesehatan. Pada pasien dengan skizofrenia, efek samping obat sangat lazim terjadi dan secara signifikan terkait dengan adanya ketidakpatuhan terhadap pengobatan. Ketidakpatuhan ini secara signifikan terkait dengan peningkatan penggunaan sumber daya kesehatan. ${ }^{28}$

Pada kasus yang bukan psikiatri juga disebutkan bahwa efek samping memerlukan biaya yang lebih tinggi. Sebuah penelitian yang dilakukan terhadap pasien asma yang menggunakan kortikosteroid oral dengan dosis yang tinggi, kelompok pasien yang mengalami efek samping mempunyai biaya perawatan kesehatan yang lebih tinggi dan penggunaan sumber daya perawatan kesehatan yang lebih bila dibandingkan dengan pasien tanpa efek samping. ${ }^{29}$

Di dalam penelitian ini, triheksifenidil merupakan obat yang paling banyak digunakan bersamaan dengan antipsikotik. Pemberian triheksifenidil kemungkinan berkaitan dengan masalah efek samping obat antipsikotik, baik untuk terapi efek samping ekstrapiramidal maupun sebagai preventif. Hasil penelitian sebelumnya menunjukkan bahwa pemberian triheksifenidil yang berupa terapi tambahan diberikan kepada pasien psikotik dua kali sehari dan kebanyakan tidak diinisiasi oleh pemeriksaan sindrom ekstrapiramidal. ${ }^{30}$

Pada tahun 2015 sampai dengan 2017, asam valproat merupakan antiepilepsi yang paling banyak digunakan diikuti oleh fenobarbital. Pada sebuah studi yang dilakukan pada pasien disabilitas intelektual dewasa dengan epilepsi, penggunaan antiepilepsi yang paling sering dilaporkan adalah asam valproat $(48,7 \%)$, karbamazepin (46,3\%) dan lamotrigin $(27,8 \%){ }^{31}$
Pada tahun 2017, terdapat penggunaan donepezil yang langsung masuk ke dalam segmen DU 90\% (dapat dilihat pada Tabel 3). Donepezil (N06DA02) merupakan obat antidemensia dan antikolinesterase. ${ }^{12}$ Sebuah kajian sistematik meta analisis tentang efikasi dan keamanan dari obat inhibitor kolinesterase donepezil, galantamin, dan rivastigmin pada penyakit alzeimer menunjukkan hasil bahwa obat-obat tersebut mampu memelihara atau memperlambat penurunan kognisi, fungsi, perilaku, dan perubahan secara global apabila dibandingkan dengan plasebo. ${ }^{32}$ Penelitian kontrol acak double blind yang dilakukan terhadap pasien perempuan yang memiliki down syndrome, penggunaan donepezil dapat secara efektif dan aman memperbaiki fungsi keseluruhan pasien dengan gangguan kognitif parah. ${ }^{33}$ Demikian pula hasil penelitian kontrol acak yang dilakukan di Cina terhadap pasien penyakit alzeimer berat menunjukkan bahwa donepezil yang diberikan selama 24 minggu lebih efektif dan menunjukkan keamanan dan tolerabilitas yang baik dibanding plasebo. ${ }^{34}$

Penggunaan donepezil pada anak-anak dan remaja menunjukkan hasil yang kontradiktif. Sebuah penelitian multisenter acak double blind yang dilakukan gagal menunjukkan manfaat apapun dari donepezil dibandingkan plasebo pada anak-anak dan remaja dengan down syndrome, meski donepezil tampaknya bisa ditoleransi dengan baik. ${ }^{35}$ Namun, hasil penelitian lain berupa sebuah laporan kasus terhadap seorang anak laki-laki usia 14 tahun yang memiliki down syndrome dan gangguan tidur dan gangguan motorik berat, perilaku autistik dan gangguan interaksi sosial serta mengalami agresivitas dan fobia terhadap air, dengan pemberian donepezil setelah pemberian L-dova dan juga inhibitor reuptake serotonin mengalami perbaikan total ke tingkat psikososial sebelumnya. ${ }^{36}$

Pada analisis cost of DU dan cost/DDD DU $90 \%$, nilai biaya pada tahun 2015 dan 2016 telah disesuaikan menjadi nilai biaya pada 
tahun 2017 dengan memperhitungkan tingkat inflasi berdasar indeks harga konsumen yang mengacu kepada Bank Indonesia, ${ }^{37}$ dengan biaya tahun 2015 dikalikan dengan 1,075 sedangkan nilai biaya tahun 2016 dikalikan dengan 1,038. Hal ini dilakukan agar analisis terhadap parameter biaya dapat dibandingkan dengan setara, tidak dipengaruhi oleh perancu berupa perubahan harga yang terjadi di setiap tahun.

Peningkatan cost of DU\% 2016 dibanding 2015 kemungkinan disebabkan oleh terjadinya peningkatan penggunaan obat asam valproat (dari 5,97 DDD/100 bed-days menjadi 314,17 DDD/100 bed-days) dan klozapin (dari 5,12 $\mathrm{DDD} / 100$ bed-days menjadi 60,25 DDD/100 bed-days) yang lebih mahal bila dibandingkan haloperidol. Sementara itu, peningkatan cost of DU 90\% tahun 2017 bila dibandingkan 2015 dan 2016 disebabkan oleh peningkatan penggunaan obat risperidon dan flufenazin parenteral depot (Rp69.300/25 mg) pada segmen DU 90\%, dengan masuknya olanzapine parenteral (Rp163.800/10 mg) pada segmen DU 90\% dan adanya penggunaan donepezil yang langsung masuk DU 90\% (Rp15.981/10 $\mathrm{mg})$. Peningkatan cost of DU $90 \%$ ini dapat diasumsikan menyebabkan peningkatan pada cost/DDD DU 90\%, yang juga mengalami peningkatan dari tahun 2015 sampai 2017.

Kekuatan penelitian ini adalah penelitian ini dapat menampilkan profil pemanfaatan semua jenis obat psikotropika yang digunakan oleh populasi remaja yang berusia 12-18 tahun dengan disabilitas intelektual baik dari aspek rata-rata pemakaian dosis (DDD) maupun dari aspek biaya. Metodologi ini dapat terus digunakan untuk mengevaluasi pemanfaatan obat psikotropika pada populasi remaja yang memiliki disabilitas intelektual pada tahuntahun berikutnya. Selain itu, hasil penelitian ini dapat pula digunakan untuk mengevaluasi penggunaan obat-obatan psikotropika pada populasi remaja dengan retardasi mental dengan cakupan yang lebih luas misalnya di seluruh
Rumah Sakit Jiwa di Indonesia.

Keterbatasan dalam penelitian ini adalah analisis dilakukan hanya berdasarkan biaya obat psikotropika, tidak termasuk biaya alat kesehatan habis pakai dan biaya tindakan tenaga kesehatan misalnya tindakan injeksi untuk sediaan parenteral. Hal ini berdasarkan pertimbangan bahwa sistem distribusi alat kesehatan habis pakai pada tahun 2015 masih menggunakan sistem tersedia di ruang rawat (floor stock), sedangkan tahun 2016 dan 2017 sudah menggunakan sistem dosis unit. Biaya tindakan injeksi untuk sediaan parenteral tidak diperhitungkan karena selama kurun waktu 2015 sampai 2017 tidak terdapat tarif tindakan injeksi. Selain itu, dalam penelitian ini biayabiaya lain selain obat yang termasuk biaya langsung medis juga tidak diperhitungkan. Selain keterbatasan dari aspek analisis biaya, penelitian ini juga tidak memperhitungkan outcome berupa efektivitas dari obat-obatan psikotropika.

Segmen DU 90\% tahun 2015 merupakan pilihan yang memiliki biaya yang paling rendah apabila dibandingkan tahun 2016 dan 2017, namun masih memberikan gambaran yang terbatas dari aspek biaya obat-obatan psikotropika, sehingga diperlukan penelitian lanjutan yang lebih komprehensif. Analisis farmakoekonomi berupa analisis efektivitasbiaya baik berdasar perspektif penyedia layanan kesehatan maupun perspektif sosial perlu dilakukan untuk mendapat bukti efektivitasbiaya dari obat-obatan psikotropika.

\section{Simpulan}

Profil penggunaan psikotropika pada pasien remaja dengan disabilitas intelektual di RS Jiwa Provinsi Jawa Barat tahun 2015-2017 diketahui dari ATC/DDD, total penggunaan DDD, DDD/100 bed-days dan drug utilization (DU) 90\%. Terdapat 19 jenis psikotropika yang digunakan pada tahun 2015, 22 jenis pada tahun 2016 dan 29 jenis pada tahun 2017. 
Risperidon (N05AX08) merupakan obat yang paling banyak digunakan pada masing-masing tahun. Biaya obat-obatan psikotropika segmen DU $90 \%$ tahun 2015 memiliki nilai biaya yang paling minimal berdasarkan perhitungan cost of DU $90 \%$ dan cost/DDD DU 90\%.

\section{Ucapan Terima Kasih}

Terima kasih kepada Manajemen Rumah Sakit Jiwa Provinsi Jawa Barat, dr. Lina Budiyanti, Sp.KJ $(\mathrm{K})$ yang memberikan masukan tentang aspek klinis dari disabilitas intelektual, Yeni Susanti,A.Md.PK., Rahadyan Krhisnadi, S.AB., dan Kasroni yang membantu pengambilan data penelitian, dr. H. Noki Irawan Saputra, Sp.KJ, Taufik Hidayat, S.Kep., Ners., MKM. dan Yuni Sofyan, A.Md.Ft., yang membantu proses kaji etik dan izin penelitian.

\section{Pendanaan}

Penelitian ini didanai oleh Badan Kepegawaian Daerah Pemerintah Provinsi Jawa Barat.

\section{Konflik Kepentingan}

Seluruh penulis menyatakan tidak terdapat potensi konflik kepentingan dengan penelitian, kepenulisan (authorship), dan atau publikasi artikel ini.

\section{Daftar Pustaka}

1. American Association on Intellectual and Developmental Disabilities. Definition of intellectual disability [Accessed on: 28 February 2018]. Available at: http://aaidd. org/intellectual-disability/definition\#. WpZ4BCklHIW

2. Maulik PK, Mascarenhas MN, Mathers CD, Dua T, Saxena S. Prevalence of intellectual disability: A meta-analysis of population-based studies. Res Dev Disabil. 2011;32(2):419-36. doi: 10.1016/j.ridd.2
010.12.018

3. Pusat Data dan Informasi Kementerian Kesehatan Republik Indonesia. Situasi penyandang disabilitas. Buletin Jendela Data dan Informasi Kesehatan. 2014;1-18.

4. LoVullo SV, Matson JL. Comorbid psychopathology in adults with autism spectrum disorders and intellectual disabilities. Res Dev Disabil. 2009; 30(6): 1288-96. doi: 10.1016/j.ridd.2009.05.004.

5. Einfeld SL, Ellis LA, Emerson E. Comorbidity of intellectual disability and mental disorder in children and adolescents: A systematic review. J Intellect Dev Disabil. 2011;36(2):137-43. doi: 10.1080 /13668250.2011.572548.

6. Tsiouris JA, Kim SY, Brown WT, Pettinger J, Cohen IL. Prevalence of psychotropic drug use in adults with intellectual disability: Positive and negative findings from a large scale study. J Autism Dev Disord. 2013;43(3):719-31. doi: 10.1007/ s10803-012-1617-6.

7. Bertelli MO, Rossi M. Update on psychopharmacology for persons with intellectual disability and/or low functioning autism spectrum disorder. $\mathrm{J}$ Mental Health Res Intellectual Disabil. 2017;10(1):31-3. doi: 10.1108/AMHID-1 0-2015-0049

8. Matson JL, Neal D. Psychotropic medication use for challenging behaviors in persons with intellectual disabilities: An overview. Res Dev Disabil. 2009;30(3): 572-86. doi: 10.1016/j.ridd.2008.08.007.

9. Romeo R, Molosankwe I. Economic evidence in intellectual disabilities: A review. Curr Opin Psychiatr. 2010;23(5): 427-31. doi: 10.1097/YCO.0 b013e3283 3 ad946

10. Shaughnessy TM, Parker FR, Hollenshead JH, Clottey EN, Rubin HW. Contemporary data and trends in the economic costs of mental disabilities. Behav Sci Law. 2017;35(2):162-177. doi: 
10.1002/bsl.2280.

11. Doran CM, Einfeld SL, Madden RH, Otim M, Horstead SK, Ellis LA, et al. How much does intellectual disability really cost? First estimates for Australia. J Intellect Dev Disabil. 2012;37(1):42-9. doi: 10.3109/13668250.2011.648609.

12. Havighurst R. Developmental tasks and education (3rd Edit.). New York: David McKay Co; 1972.

13. Ghaffary S, Maleki TE, Abdollahpor J, Hamishehkar H. Measurement and comparison of inpatient antibiotic use in five different hospitals in Tabriz. Pharm Sci. 2017;23(1):37-41 doi: 10.15171/PS. 2017.06

14. World Health Organization. Collaborating centre for drug statistics methodology, guidelines for ATC classification and DDD assignment 2017. Oslo: World Health Organization; 2016.

15. Kementerian Kesehatan Republik Indonesia. Pedoman teknis analisis farmakoekonomi di fasilitas kesehatan. Jakarta: Kementerian Kesehatan Republik Indonesia; 2016.

16. Maenner MJ, Blumberg SJ, Kogan MD, Christensen D, Yeargin-Allsopp M, Schieve LA. Prevalence of cerebral palsy and intellectual disability among children identified in two US National Surveys, 2011-2013. Ann Epidemiol. 2016;26(3): 222-6. doi: 10.1016/j.annepid em.2016.0 1.001

17. Westerinen H, Kaski M, Virta LJ, Kautiainen H, Pitkälä KH, Iivanainen M. The nationwide register-based prevalence of intellectual disability during childhood and adolescence. J Intellect Disabil Res. 2017;61(8):8029. doi: 10.1111/jir.123 51

18. Bourke J, de Klerk N, Smith T, Leonard H. Population-based prevalence of intellectual disability and autism spectrum disorders in Western Australia: A comparison with previous estimates. Medicine. 2016; 95(21):e3737. doi: 10.1097/MD.0000000
000003737.

19. Leucht S, Corves C, Arbter D, Engel RR, Li C, Davis JM. Second-generation versus first-generation antipsychotic drugs for schizophrenia: A meta-analysis. Lancet. 2009;373(9657):31-41. doi: 10.1016/S01 40-6736(08)61764-X.

20. Perry BI, Kwok HF, Mendis J, Purandare $\mathrm{K}$, Wijeratne A, Manjubhashini S, et al. Problem behaviours and psychotropic medication use in intellectual disability: A multinational cross-sectional survey. J Intellect Disabil Res. 2018;62(2):140-9. doi: 10.1111/jir. 12471.

21. Ji NY, Findling RL. Pharmacotherapy for mental health problems in people with intellectual disability. Curr Opin Psychiatry. 2016;29(2):103-25. doi: 10.1 097/YCO.0000000000000233.

22. Capone GT, Goyal P, Grados M, Smith B, Kammann H. Risperidone use in children with down syndrome, severe intellectual disability, and comorbid autistic spectrum disorders: A naturalistic study. J Dev Behav Pediatr. 2008;29(2):106-16. doi: 10.1097/DBP.0b013e318165c100.

23. Unwin GL, Deb S. Efficacy of atypical antipsychotic medication in the management of behaviour problems in children with intellectual disabilities and borderline intelligence: A systematic review. Res Dev Disabil. 2011;32(6): 2121 -33. doi: 10.1016/j.ridd. 2011.07.031.

24. Cohen D, Raffin M, Canitano R, Bodeau $\mathrm{N}$, Bonnot O, Périsse D, et al. Risperidone or aripiprazole in children and adolescents with autism and/or intellectual disability: A bayesian meta-analysis of efficacy and secondary effects. Res Autism Spectr Disord. 2013;7(1):167-75. doi: 10.1016/j. rasd.2012.08.001

25. McQuire C, Hassiotis A, Harrison B, Pilling S. Pharmacological interventions for challenging behaviour in children with intellectual disabilities: A systematic 
review and meta-analysis. BMC Psychiatry. 2015;15(1):303. doi: 10.1186/s12888-01 5-0688-2.

26. Pisano S, Catone G, Veltri S, Lanzara V, Pozzi M, Clementi E, et al. Update on the safety of second generation antipsychotics in youths: A call for collaboration among paediatricians and child psychiatrists. Ital J Pediatr. 2016;42(1):51. doi: 10.1186/s1 3052-016-0259-2

27. Sheehan R, Horsfall L, Strydom A, Osborn D, Walters K, Hassiotis A. Movement side effects of antipsychotic drugs in adults with and without intellectual disability: UK population-based cohort study. BMJ open. 2017;7(8):e017406. doi: 10.1136/b mjopen-2017-017406

28. Dibonaventura M, Gabriel S, Dupclay L, Gupta S, Kim E. A patient perspective of the impact of medication side effects on adherence: Results of a cross-sectional nationwide survey of patients with schizophrenia. BMC Psychiatry. 2012;12 (1):20. doi: 10.1186/1471-244X-12-20.

29. Luskin AT, Antonova EN, Broder MS, Chang EY, Omachi TA, Ledford DK. Health care resource use and costs associated with possible side effects of high oral corticosteroid use in asthma: A claims-based analysis. Clinicoecon Outcomes Res. 2016;8:641-8. doi: 10.2147/CEOR. S115025

30. Azmi AN, Desrini S. A cross sectional study of trihexyphenidyl utilization on patient receiving antipsychotic therapy. Jurnal Kedokteran dan Kesehatan Indonesia. 2016;7(3):102-8. doi: 10.2088 5/JKKI.Vol7.Iss3.art5

31. O'Dwyer M, Peklar J, Mulryan N, McCallion P, McCarron M, Henman MC. Prevalence and patterns of anti-epileptic medication prescribing in the treatment of epilepsy in older adults with intellectual disabilities. J Intellect Disabil Res. 2018; 62(3):245-61. doi: 10.1111/jir.12461

32. Hansen RA, Gartlehner G, Webb AP, Morgan LC, Moore CG, Jonas DE. Efficacy and safety of donepezil, galantamine, and rivastigmine for the treatment of Alzheimer's disease: A systematic review and metaanalysis. Clin Interv Aging. 2008;3(2):211 -25 .

33. Kondoh T, Kanno A, Itoh H, Nakashima M, Honda R, Kojima M, et al. Donepezil significantly improves abilities in daily lives of female down syndrome patients with severe cognitive impairment: A 24week randomized, double-blind, placebocontrolled trial. Int J Psychiatry Med. 2011; 41(1):71-89. doi: 10.2190/PM.41.1.g

34. Jia J, Wei C, Jia L, Tang Y, Liang J, Zhou A, et al. Efficacy and safety of donepezil in chinese patients with severe alzheimer's disease: A randomized controlled trial. J Alzheimers Dis. 2017;56(4):1495-504. doi: 10.3233/JAD-161117.

35. Kishnani PS, Heller JH, Spiridigliozzi GA, Lott I, Escobar L, Richardson S, et al. Donepezil for treatment of cognitive dysfunction in children with Down syndrome aged 10-17. Am J Med Genet A. 2010;152A(12):3028-35. doi: 10.1002 /ajmg.a.33730.

36. Tamasaki A, Saito Y, Ueda R, Ohno K, Yokoyama K, Satake T, et al. Effects of donepezil and serotonin reuptake inhibitor on acute regression during adolescence in down syndrome. Brain Dev. 2016;38(1):113-7. doi: 10.1016/j.brainde v.2015.06.006.

37. Bank Sentral Republik Indonesia. Inflation report (consumer price index) base on year on year measurement [Accessed on: 22 December 2017]. Available at: http:// www.bi.go.id/en/moneter/inflasi/data/De fault.aspx

(C) 2018 Nur et al. The full terms of this license incorporate the Creative Common Attribution-Non Commercial License (https://creativecommons. org/licenses/by-nc/4.0/). By accessing the work you hereby accept the terms. Non-commercial use of the work are permitted without any further permission, provided the work is properly attributed. 